International Journal of Current Advanced Research

ISSN: O: 2319-6475, ISSN: P: 2319 - 6505, Impact Factor: SJIF: 5.995

Available Online at www.journalijcar.org

Volume 6; Issue 4; May 2017; Page No. 3968-3970

DOI: http://dx.doi.org/10.24327/ijcar.2017.3970.0408

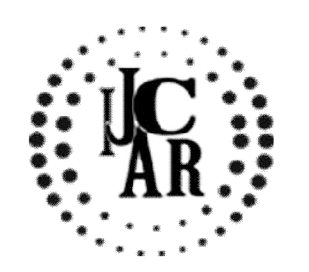

Research Article

\title{
EVALUATION OF GROUND WATER QUALITY OF KASGANJ TOWN IN SUMMER
}

\author{
Pramod Kumar
}

Chemistry Govt. Degree College Manikpur (Chitrakoot) 210208 U.P. India

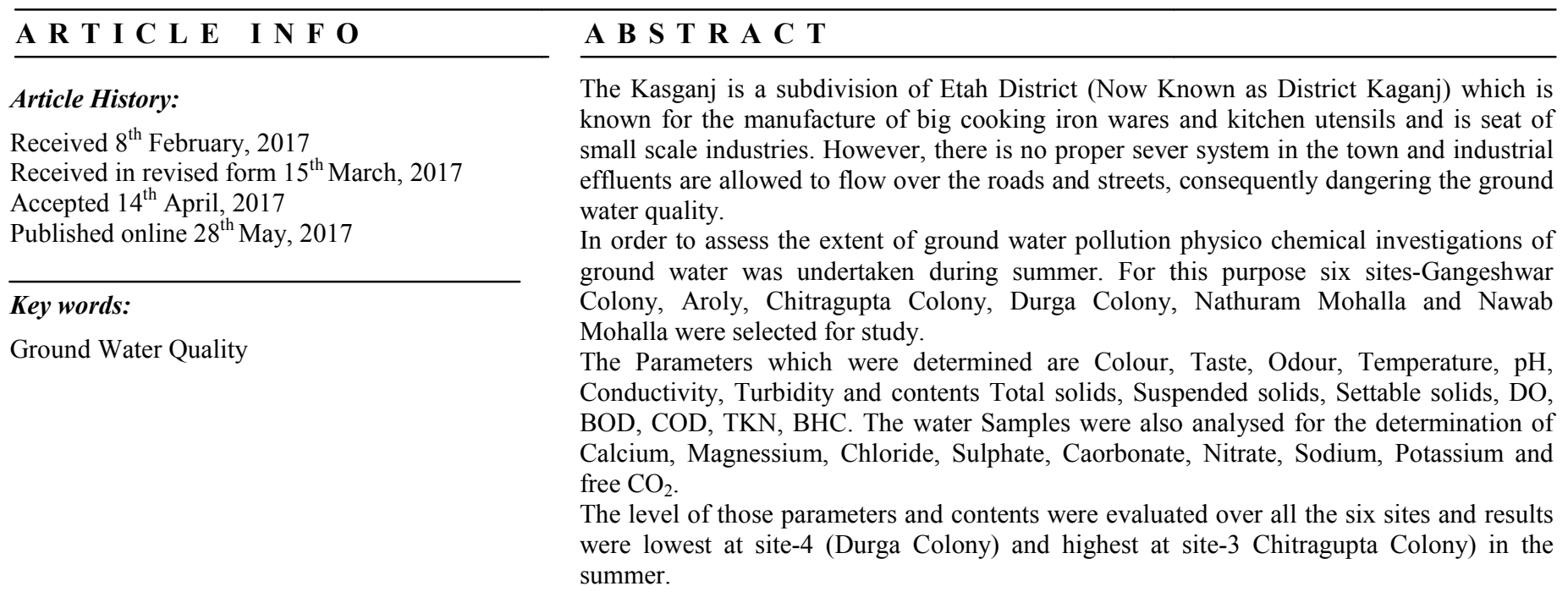

Copyright $@ 2017$ Pramod Kumar. This is an open access article distributed under the Creative Commons Attribution License, which permits unrestricted use, distribution, and reproduction in any medium, provided the original work is properly cited.

\section{INTRODUCTION}

The term pollution derived from the latin word pollure and means to soil ${ }^{1}$ or to defile. The term pollution, contamination, nuisance and degradation often are used simultaneously to describe faulty conditions of surface waters. Pollution have defined as an unavoidable ${ }^{1}$ change in Physico - chemical and biological characteristic of our air, land and water that may or will hostilely affect human life or that of other describe species or industrial process or deteriorate our natural resources.

Pollution of water is responsible for ${ }^{2}$ a very large number of mortalities and incapacitations in the word. Polluted state of water resources has led to a steady decline in fisheries and has also affected the irrigation land. Water no longer remains a free good. Availability of clean water is going to become the greatest 'constraint for the development of tomorrow.

Man has tried to cope with this scenario and has rapidly advanced its efforts to counteract this malady. In past few decades $^{3}$ natural and polluted waters have been studied in detail all over the world and considerable data is now available on most kind of pollutants and their effect on ecosystem as well as on organisms.

*Corresponding author: Pramod Kumar

Chemistry Govt. Degree College Manikpur (Chitrakoot)

210208 U.P. India
Sources of pollution can be divided into two groups natural and cultural. The sources can be further classified as either point or non point. Point sources enter the pollution transport routes at discrete unidentifiable locations and usually can be measured directly or otherwise quantified and their impact can be evaluated directly. Pollution from non point sources can be related to weathering of minerals, erosion of virgin lands and forests including residues of natural vegetarian or artificial or semi artificial sources. The last can be directly related to human activity such as fertilizer applications or use of agricultural chemicals for controlling weeds or insect erosion of soil materials from agricultural farming areas and animal feed lots, construction sites, transportation of dust and litter on impervious urban surfaces.

Ground water is usually traced back to four main origins. Industrial domestic agricultural, environmental pollution, each family is being divided up into continuous and accidental types.

\section{Experimental and Discussion in the month of May}

In this month temperature ranged between $30.10-30.80^{\circ} \mathrm{C}$. Temperature in this month has not shown remarkable change at any site. Highest value was recorded at site III (Chitragupt Colony). $\mathrm{pH}$ of water dependent upon the relative quantities of $\mathrm{CO}_{3}^{--}, \mathrm{HCO}_{3}^{--}$and $\mathrm{Ca}^{++}$(Zafar,1996). In this month the six sites $\mathrm{pH}$ followed the order site-III $>$ Site-I $>$ Site- II $>$ Site- 
VI $>$ Site $>$ V Site IV. It ranged between 7.52-8.02. It was found maximum at site-III (Chitragupta Colony) and minimum at site-IV (Durga Colony).

In this month Conductivity fluctuated between 649.00-671.00 us/cm. Lowest value was recorded at site-IV (Durga Colony) and highest at site-III. (Chitragupta Colony). Obviously dissolved solids are in high concentration at site-III (Chitragupta Colony). At the six sites it followed order site III $>$ site-V $>$ site-I $>$ site-VI $>$ site-II $>$ site-IV .

Turbidity ranged between 5.27-14.90 NTU. Highest value of turbidity was recorded at site III (Chitragupta Colony) and lowest at site IV (Durga Colony). It followed the order siteIII $>$ site-VI $>$ site-II $>$ site-V $>$ site-I $>$ site-IV. Turbidity was under the permissible limit for drinking water at the sites I,II,III and IV.

Calcium content at the six sites followed the order siteIII $>$ site-VI $>$ site- $\mathrm{V}>$ site-I $>$ site-II $>$ site-IV. It fluctuated between 90.04-99.29 mg/lt. Highest value was recorded at site- III (Chitragupta Colony) and lowest at site- IV (Durga Colony). It was under the permissible limit for drinking water $(200 \mathrm{mg} / \mathrm{lt}$, ISI, 1991 but exceeded the desirable limit (75mg/lt, ISI, 1991) at all the six sites.

Magnesium content followed the same order as calcium (siteIII $>$ site- $\mathrm{VI}>$ Site- $\mathrm{V}>$ site-I $>$ site-II $>$ site-IV). It ranged between 61.80-74.40 mg/lt. Highest value was recorded at site- III (Chitragupta Colony) and lowest and site-IV (Durga Colony). It was above the permissible limit for drinking water (30 $\mathrm{mg} / \mathrm{lt}$, ISI, 1991) at all the six sites.

The concentration of total solids ranged between 658.00$706.00 \mathrm{mg} / \mathrm{lt}$. The highest value was recorded at site-III (Chitragupta Colony) and lowest at site-IV (Durga Colony). At the six sites it followed the order site III $>$ site-VI $>$ site$\mathrm{V}>$ site-II $>$ site-I $>$ site-IV.Total solids contents were above the desirable limit $500 \mathrm{mg} / \mathrm{lt}$ at all six sites. Actually in many parts of the world; water with dissolved solids concentration ranging from 2000-4000 $\mathrm{mg} / \mathrm{lt}$ is also used and no psychological effect were reported.

Suspended solids ranged between 21-25.8 mg/lt. Highest value was recorded at site-III (Chitragupta Colony) and lowest at site- IV (Durga Colony). It followed the order siteIII $>$ site-VI $>$ site-V $>$ site-I $>$ site-II $>$ site-IV .

Settleable solids varied from $6.10-9.50 \mathrm{mg} / \mathrm{lt}$. Highest value was recorded at site-III (Chitragupta Colony) and lowest at site-IV (Durga Colony). It followed the order site-III $>$ siteVI $>$ site- $\mathrm{V}>$ site-I $>$ site-II $>$ site-IV .

The chloride content followed the order site-III $>$ site-VI $>$ siteI $>$ site-V $>$ site-II $>$ site-IV. In this month it varied from 351$368 \mathrm{mg} / \mathrm{lt}$. normally increases as the mineral content increases. It is found in the form of $\mathrm{Na}, \mathrm{K}$ and $\mathrm{La}$ salts. It shows the degree of pollution of animal origin. In this month it varied from 352-368 mg/lt. The lowest value was recorded at site-IV (Durga Colony) and highest at site-III (Chitragupta Colony). At all sites chloride content surpassed the limit for drinking water $(250 \mathrm{mg} / \mathrm{lt}$, ISI, 1991) but was found under the permissible limit for drinking water $(1000 \mathrm{mg} / \mathrm{lt}$, ISI, 1991). Klien (1957) found direct correlation between ahloride and pollution load.

Stiever (1967) has reported that the sulphate reduces to $\mathrm{H}_{2} \mathrm{~S}$ very quickly under high organic pollution and depleted oxygen conditions. It followed the order site-III $>$ site-VI $>$ site$\mathrm{V}>$ site-I $>$ site-II $>$ site-IV. In this month sulphate content ranged between 163.00-178.00 mg/lt. Highest value was recorded at site - III (Chitragupta Colony) and lowest at siteIV (Durga Colony). In this month it was found within the permissible limit (400 mg/lt, ISI, 1991) at all sites.

Carbonate at the six sites followed the order site-III $>$ site$\mathrm{VI}>$ site-V $>$ site-II $>$ site-I $>$ site-IV. It varied from 5.26-7.76 $\mathrm{mg} / \mathrm{lt}$. Highest value was recorded at site-III (Chitragupta Colony) and lowest at site-IV (Durga Colony).

Bicarbonate followed the order site-III $>$ site- $\mathrm{VI}>$ site- $\mathrm{V}>$ siteI $>$ site-II $>$ site-IV. It varied from $582-621 \mathrm{mg} / \mathrm{lt}$. Highest value was recorded at site-III (Chitragupta Colony) and lowest at site-IV (Durga Colony).

Free $\mathrm{CO}_{2}$ followed the order site-III $>$ site-VI $>$ site-II $>$ siteV $>$ site- I $>$ site- IV. It varied from 10.90-14.60 mg/lt. Highest value was recorded at site-III (Chitragupta Colony) and lowest at site-IV (Durga Colony). Water at all sites is corrosive in nature as $\mathrm{CO}_{2}$ always exceeds the limit $(6 \mathrm{mg} / \mathrm{lt}$, Kudesia, 1991). The high $\mathrm{CO}_{2}$ level here is an indication of pollutants in water and not much harmful for aquatic life. The higher value of free $\mathrm{CO}_{2}$ might be due to increased rate of decomposition of organic matter by microbes in bottom resulting in the rapid production of free $\mathrm{CO}_{2}$.

In this month nitrate fluctuated between $14.00-20.01 \mathrm{mg} / \mathrm{lt}$. It followed the order site-III $>$ site-VI $>$ site-V $>$ site-I $>$ Site-II $>$ siteIV. Highest value was recorded at site-III (Chitragupta Colony) and lowest at site-IV (Durga Colony). Site-III is situated near the open ground which is suitable for agriculture. Its highest value at site-III was due to the influx of nitrogenous fertilizers through agricultural lands.

Nitrite fluctuated between $1.63-5.10 \mathrm{mg} / \mathrm{lt}$. It followed the order site-III $>$ site-VI $>$ site-V $>$ site-II $>$ site-I $>$ site-IV. Highest value was recorded at site-III (Chitragupta Colony) and lowest at site-IV (Durga Colony). At the site I, II, IV nitrite content was found under the provisional guidelines for drinking water (3mg/lt, WHO, 1996).

Sodium varied from $346-372 \mathrm{mg} / \mathrm{lt}$. It followed the order siteIII $>$ site-II $>$ site-VI $>$ site-V $>$ site-I $>$ site-IV. Highest value was recorded at site-III (Chitragupta Colony) and lowest at site-IV (Durga Colony). No permissible limit has been prescribed of sodium for drinking water.

The concentration of potassium is trivial in most drinking waters. It fluctuated between 7.78- $9.98 .00 \mathrm{mg} / \mathrm{lt}$. It followed the order site-III $>$ site-VI $>$ site- $\quad \mathrm{V}>$ site-II $>$ site-I $>$ site-IV. Highest value was recorded at site-III (Chitragupta Colony) and lowest at site-IV (Durga Colony).

$\mathrm{DO}$ in this month followed the order site-III $>$ site-VI $>$ site-V $>$ site-II $>$ site-I $>$ site-IV. It varied from 5.22-7.91 mg/lt. Highest value was recorded at site-III (Chitragupta Colony) and lowest at site-IV (Durga Colony). DO at the sites, I, IV was found below the minimum desirable limit $6 \mathrm{mg} / \mathrm{lt}$ for drinking water (1991).

BOD in this month fluctuated between 9.50-11.51 mg/lt. Highest value was recorded at site-III (Chitragupta Colony) and lowest at site-IV (Durga Colony). It followed the order site-III $>$ site- $\mathrm{VI}>$ site- $\mathrm{V}>$ site-II $>$ site-I $>$ site-IV. BOD at all sites exceeded the maximum permissible limit of $2 \mathrm{mg} / \mathrm{lt}$ for drinking water. Ostensibly cause of the high BOD i.e. organic 
pollution at the site-III (Chitragupta Colony) is a big sewage disposal, drain sides of which are thickly inhabited by people of lowest middle class who have installed hand pumps in their houses for maintaining their need of potable water and water for cleaning purpose. BOD is lowest at the site-IV (Durga Colony) because at this site the community habits are comparatively neat and clean.

COD in this month followed the order site-III $>$ site-VI $>$ site- $\mathrm{V}$ $>$ site- II $>$ site- I $>$ site- IV. I fluctuated between $t$ 65.58-85.52 $\mathrm{mg} / \mathrm{lt}$. Highest value was recorded at site- III (Chitragupta Colony) and lowest at site- I (Gangeshwar Colony).

TKN followed the order site-III $>$ site-VI $>$ site-V $>$ site-II$>$ I $>$ site-IV. It varied from 10.24-14.75 mg/lt. Highest value was recorded at site-III (Chitragupta Colony) and lowest at site-IV (Durga Colony). It is lowest at site-IV because it is least dirty and maintaining some hygiene and community habits are comparatively neat and clean.

In this month water was found to be colourless at sites II, IV, $\mathrm{V}$ and light yellow at sites I,VI,III. Light yellow colour of water indicates the presence of sand. Taste of water in this month was agreeable at sites I, IV,V and disagreeable at sites I, III, VI.

Odour in this month was unobjectionable at sites I, IV,V. and objectionable at sites II, III, VI.
Similarly various parameters and contents were determined and discussed in the month of March earlier.

\section{Summary}

Durga Colony (site-IV) is marked with qualities of adequately clean water. Worst affected is Chitragupta Colony (site-III) due to the bad community habits, rivulets and gutters delivering fifthly and boggy water, a big sewage disposal drain is going through middle of the colony, sides of which are thickly inhabited by people of lower middle class; who have installed hand pumps in their houses for meeting their needs of potable water and water for cleaning purpose.

\section{References}

1. Ashok K.Keshari and Dutta B (1996). Integrated optimal management of ground water pollution and withdrawal. Ground water 34(1), 104-113.

2. Barwah Anil Kumar, Sharma Ntini Rathni N and Chaudhary Prakash (1995): Assessment of ground water quality around oil installation of Rudra Sagar Assam India Eco. Envi. Conserv.1 (1-4).

3. B.K.Handa (1976): Modern methods of water analysis Tech. Annual No. 3C.G.W. B404.

\section{How to cite this article:}

Pramod Kumar (2017) 'Evaluation Of Ground Water Quality Of Kasganj Town In Summer', International Journal of Current Advanced Research, 06(05), pp. 3968-3970.

DOI: http://dx.doi.org/10.24327/ijcar.2017.3970.0408 